\title{
MANFAAT RELAKSASI OTOT PROGRESIF BAGI KLIEN DM TIPE II UNTUK MENGURANGI GEJALA FATIGUE
}

\section{Benefits Of Progressive Muscle Relaxation For Type II DM Clients To Reduce Fatigue Symptoms}

\author{
Reny Sulistyowati ${ }^{*}$ \\ *'Poltekkes Kemenkes Palangka \\ Raya, Palangka Raya, \\ Kalimantan Tengah, Indonesia \\ *email: \\ reny_sulis@poltekkes-palangkaraya.ac.id
}

\section{Kata Kunci:}

DM tipe II

Gejala Fatigue

Latihan Otot Progresif

\author{
Keywords: \\ Type II DM \\ Fatigue Symptom \\ Progressive Muscle Relaxation
}

\begin{abstract}
Abstrak
Gejala fatigue adalah keluhan klinis yang meluas di antara orang dewasa dengan diabetes tipe 2. Fluktuasi kadar glukosa dapat menyebabkan kelelahan. Beberapa faktor yang dihubungkan dengan kelelahan pada pasien diabetes, termasuk faktor fisiologis misalnya hipoglikemia atau hiperglikemia, faktor psikologis seperti depresi terkait dengan diabetes. Relaksasi otot progresif merupakan suatu prosedur untuk mendapatkan relaksasi pada otot melalui dua langkah yaitu dengan memberikan tegangan pada suatu kelompok otot dan menghentikan tegangan tersebut kemudian memusatkan perhatian pada bagaimana otot tersebut menjadi rileks, merasakan sensasi rileks dan kelelahan berkurang. Tujuan penelitian untuk mengidentifikasi pengaruh relaksasi otot progresif terhadap gejala fatigue pada klien DM tipe II pada 15 orang kelompok kontrol dan 15 orang kelompok intervensi. Metode penelitian menggunakan desain quasi experiment dengan pendekatan desain control group pretest-posttest, terdiri dari satu perlakuan (pada kelompok intervensi) dan kelompok kontrol. Analisis data dilakukan secara univariat serta analisis bivariat dengan uji t-independent dan t-dependent. Hasil Uji wilcoxon pada kelompok intervensi dan kelompok kontrol didapatkan hasil signifikansi $p$-value sebesar 0.002 (< 0.05), artinya terdapat perbedaan bermakna gejala fatigue pada kelompok intervensi sebelum dan sesudah intervensi. Hal ini menunjukkan terdapat penurunan gejala fatigue pada kelompok intervensi sebelum dan setelah dilakukan terapi kombinasi $\mathrm{OHO}$ dan latihan relaksasi otot progresif (sebelumnya rata-rata responden kelompok intervensi mengalami gejala fatigue berat, setelah di lakukan intervensi, rata-rata nilai gejala fatigue berubah menjadi fatigue ringan). Kesimpulan: pemberian relaksasi otot progresif dikombinasikan dengan terapi $\mathrm{OHO}$ dapat mengurangi gejala fatigue dibandingkan hanya diberikan terapi $\mathrm{OHO}$.
\end{abstract}

\begin{abstract}
Fatigue is a widespread clinical complaint among adults with type 2 diabetes. Fluctuating glucose levels can cause fatigue. Several factors are associated with fatigue in diabetic patients, including physiological factors such as hypoglycemia or hyperglycemia, psychological factors such as depression associated with diabetes. Progressive muscle relaxation is a procedure to get relaxation in the muscles through two steps, namely by applying tension to a muscle group and stopping the tension then focusing on how the muscle relaxes, feeling the sensation of relaxation and fatigue is reduced. The aim of this study was to identify the effect of progressive muscle relaxation on fatigue symptoms in type II DM clients in 15 control groups and 15 intervention groups. The research method used a quasi experimental design with a pretest-posttest control group design approach, consisting of one treatment (in the intervention group) and a control group. Data analysis was performed using univariate and bivariate analysis using t-independent and $t$-dependent tests. Wilcoxon test results in the intervention group and the control group showed a significant $p$-value of $0.002(<0.05)$, meaning that there was a significant difference in fatigue symptoms in the intervention group before and after the intervention. This shows that there was a decrease in fatigue symptoms in the intervention group before and after combination $\mathrm{OHO}$ therapy and progressive muscle relaxation exercises (previously the average respondent in the intervention group experienced symptoms of severe fatigue, after intervention, the average value of fatigue symptoms turned into mild fatigue ). Conclusion: Progressive muscle relaxation combined with $\mathrm{OHO}$ therapy can reduce symptoms of fatigue compared to only $\mathrm{OHO}$ therapy.
\end{abstract}

external parties.

(c) year The Authors. Published by Institute for Research and Community Services Universitas Muhammadiyah Palangkaraya. This is Open Access article under the CC-BY-SA License (http://creativecommons.org/licenses/by-sa/4.0/). DOI: https://doi.org// 0.33084/jsm.vxix.xxx. 


\section{PENDAHULUAN}

Diabetes adalah penyakit kronis serius yang terjadi karena pankreas tidak menghasilkan cukup insulin (hormon yang mengatur gula darah atau glukosa), atau ketika tubuh tidak dapat secara efektif menggunakan insulin yang dihasilkannya. Diabetes adalah masalah kesehatan masyarakat yang penting, menjadi salah satu dari empat penyakit tidak menular prioritas yang menjadi target tindak lanjut oleh para pemimpin dunia. Jumlah kasus dan prevalensi diabetes terus meningkat selama beberapa dekade terakhir (World Health Organization, 2016).

Diabetes menyebabkan I,5 juta kematian pada tahun 20I2. Gula darah yang lebih tinggi dari batas maksimum mengakibatkan tambahan 2,2 juta kematian, dengan meningkatkan risiko penyakit kardiovaskular dan lainnya. Empat puluh tiga persen (43\%) dari 3,7 juta kematian ini terjadi sebelum usia 70 tahun. Persentase kematian yang disebabkan oleh diabetes yang terjadi sebelum usia 70 tahun lebih tinggi di negara-negara berpenghasilan rendah dan menengah daripada di negara-negara berpenghasilan tinggi (World Health Organization, 2016).

Langkah pertama dalam mengelola diabetes melitus selalu dimulai dengan pendekatan non farmakologis, yaitu melakukan tindakan seperti tidak makan berlebihan, menjaga berat badan, dan rutin melakukan aktivitas fisik. Olahraga juga dapat secara efektif mengontrol diabetes, antara lain dengan melakukan senam khusus diabetes, berjalan kaki, bersepeda, dan berenang. Diet dipadu dengan olahraga merupakan cara efektif mengurangi berat badan, menurunkan kadar gula dan mengurangi stres.

Kelelahan adalah keluhan klinis yang meluas di antara orang dewasa dengan diabetes tipe 2, hal ini telah dikaitkan langsung dengan kesehatan yang dilaporkan buruk dan kemungkinan merupakan hambatan utama bagi keberhasilan pengelolaan diabetes. Meskipun demikian, ada beberapa data menggambarkan besarnya, keparahan, atau etiologi kelelahan terkait diabetes
(Fritschi C, C, Quinn, L, Hacker, E.D, Penckofer, S.M, n.d.). Kelelahan pada diabetes tipe 2 dapat disebabkan oleh dua faktor, yaitu faktor endokrin dan nonendokrin. Faktor non-endokrin meliputi penurunan kondisi fisik, pola tidur yang buruk, konsumsi alkohol dan kafein, dan konsumsi obat-obatan (gaya hidup). Diet yang tidak sehat dapat menyebabkan kekurangan gizi makronutrien atau mikronutrien atau ketosis kelaparan, yang berarti penderita diabetes kekurangan energi (gizi) dan memiliki kondisi medis umum seperti anemia, elektrolisis, dan defisiensi vitamin multipel. Kondisi ini ditandai oleh kelelahan (kondisi medis) dan gangguan psikologis dapat memperburuk kelelahan pada diabetes tipe 2 (psikologis). Penyebab endokrin kelelahan pada diabetes tipe 2 meliputi kontrol glikemik yang buruk, komplikasi diabetes, dan endokrinopati (diabetes) yang terjadi bersamaan. Penyakit seperti hipotiroidisme, penyakit Addison, sindrom Cushing dan hipotiroidisme, jika dibiarkan tidak dikenali dan/atau tidak diobati, dapat memperburuk kelelahan pasien diabetes tipe 2 (endokrin). Obat-obatan seperti kortikosteroid, beta blocker, diuretik, dan statin juga dapat menyebabkan kelelahan (iatrogenik) (Kalra, S., \& Sahay, 2018).

Beberapa faktor yang dihubungkan dengan kelelahan pada pasien diabetes, termasuk faktor fisiologis misalnya hipoglikemia atau hiperglikemia, faktor psikologis seperti depresi dan kesusahan terkait dengan penyakit ini. Faktor epidemiologi seperti usia dan latar belakang pendidikan dan faktor terkait kesehatan (misalnya durasi penyakit dan riwayat komorbiditas). Hipoglikemia yang sering terjadi selama pengobatan diabetes sering dicurigai menjadi penyebab kelelahan (Seo, Y.M., Hahm, J.R., Kim, T.K., Choi, 20I5).

Gejala kelelahan kerja menurut (Maurits, 2010) antara lain:

a. Gejala yang berpeluang pada munculnya rasa penurunan kesiagaan dan perhatian, penurunan dan hambatan persepsi, cara berpikir, sikap anti social,dan semangat, serta kehilangan inisiatif. 
b. Gejala umum yang seringkali juga menyertai gejalagejala diatas adalah seperti hilang nafsu makan, serta gangguan pencernaan. Selain itu muncul pula gejala tidak spesifik misalkan berupa kecemasan, perubahan tingkah laku, kegelisahan, dan sukar tidur. Kelelahan kerja ini tidak hanya muncul setelah jam kerja selesai tetapi juga dapat dirasakan sebelum mulai bekerja, kelelahan ini disebut dengan clinical fatigue.

Sampai saat ini belum ada cara untuk mengukur tingkat kelelahan secara langsung. Pengukuranpengukuran yang dilakukan oleh para peneliti sebelumnya hanya berupa indikator yang menunjukkan terjadinya kelelahan akibat kerja (Tarwaka, 20l3). Pengukuran kelelahan dapat dilakukan dengan enam metode yang berbeda, yaitu:

a. Kualitas dan Kuantitas Hasil Kerja

Pada metode ini, hasil kerja digambarkan sebagai jumlah proses kerja dan waktu yang digunakan setiap unit proses atau jumlah operasi yang dilakukan setiap unit waktu. Metode ini biasanya digunakan sebagai pengukuran tidak langsung karena banyak faktor yang perlu dipertimbangkan seperti target produksi, perilaku psikologis dalam kerja, dan faktor sosial. (Tarwaka, 2013).

b. Perasaan Kelelahan Secara Subjektif

Saat ini telah ada alat untuk mengukur kelelahan dengan menggabungkan beberapa indikator untuk menginterpretasikan hasil yang dapat dipercaya. Mengutamakan perasaan subjektif terhadap kelelahan perlu diperhatikan. Kuesioner khusus digunakan untuk menilai perasaan kelelahan secara subyektif. Subjective Self Rating Test (SSRT) dari Industrial Fatigue Research Committee (IFRC) Jepang, merupakan salah satu kuesioner yang dibuat pada tahun 1967, berisi gejala kelelahan umum yang dapat untuk mengukur tingkat kelelahan subjektif (Tarwaka, 20/3). Kuesioner ini berisi 30 pertanyaan sebagai indicator yang terdiri dari 10 pertanyaan sebagai indikator tentang pelemahan kegiatan, 10 pertanyaan sebagai indicator tentang pelemahan motivasi, dan 10 pertanyaan sebagai indikator tentang gambaran kelelahan fisik.

c. The Electroencephalograph

The Electroencephalograph adalah alat ukur kelelahan yang akhir-akhir ini sesuai dengan standar riset di laboratorium, yaitu berupa penempelan elektroda pada permukaan kulit kepala untuk menangkap aktivitas listrik di otak. Setelah itu ditafsirkan sebagai sinyal yang menunjukkan keadaan kelelahan dan mengantuk (Bridger, 2003).

d. Mengukur Frekuensi Subjektif Kelipan Mata (Flicker Fusion Eyes Test)

Dalam kondisi yang lelah, kemampuan tenaga kerja untuk melihat kelipan akan berkurang. Semakin lelah akan semakin panjang waktu yang diperlukan untuk jarak antara dua kelipan. Metode ini, disamping untuk mengukur kelelahan juga menunjukkan keadaan kewaspadaan tenaga kerja (Tarwaka, 20I3).

e. Pengujian Psikomotor

Pengujian psikomotor mengukur fungsi-fungsi yang melibatkan persepsi, interpretasi,dan reaksi motorik. Uji yang sering digunakan adalah pengukuran waktu reaksi (Reaction Timer Test) (Tarwaka, 2013). Reaction timer dalah jangka waktu dari adanya pemberian suatu rangsang sampai kepada suatu kesadaran atau dilaksanakan gerakan/kegiatan. Dalam uji Reaction Timer dapat digunakan rangsangan berupa nyala lampu yang kemudian pekerja akan meresponnya, sehingga dapat dihitung waktu yang dibutuhkan pekerja untuk merespon rangsangan tersebut. Pemanjangan waktu reaksi merupakan petunjuk adanya perlambatan pada proses faal syaraf dan otot (Koesyanto, H dan Pawenang, 2005). Pengukuran waktu reaksi dilakukan sebanyak 5 
kali, setiap hasil pengukuran dijumlahkan, kemudian diambil nilai rata-ratanya. Eksperimen menggunakan uji Reaction Timer sangat penting dan menarik. Hal tersebut di karenakan hasil yang di dapatkan dari pengukuran ini tidak hanya sekedar mengetahui perbedaan kecepatan persepsi individu, akan tetapi juga mampu mendapatkan informasi mengenai kegunaan fungsi sistem syaraf yaitu atensi, kemampuan proses persepsi,dan proses kecepatan reaksi (Koesyanto, H dan Pawenang, 2005).

f. Pengujian Mental

Pada metode ini konsentrasi merupakan salah satu pendekatan yang dapat digunakan untuk menguji ketelitian dan kecepatan menyelesaikan pekerjaan. Bourdon Wiersma Test merupakan salah satu alat yang dapat digunakan untuk menguji kecepatan, ketelitian, dan konsentrasi. Hasil test akan menunjukkan bahwa semakin lelah seseorang maka tingkat kecepatan, ketelitian, dan konsentrasi akan semakin rendah. Namun demikian Bourdon Wiersma Test lebih tepat untuk mengukur kelelahan akibat aktivitas atau pekerjaan yang lebih bersifat mental (Tarwaka., Solichul HA., 2004).

\section{METODOLOGI}

Data telah dilakukan uji normalitas dan uji homogenitas sebagai syarat sebelum melakukan uji parametris. Ethichal Clearance penelitian ini telah dilakukan pemeriksaan kaji etik oleh tim Komisi Etik Fakultas Kedokteran Universitas Palangka Raya. Alat pengumpul data adalah Skala Kelelahan Functional Assessment Chronic Illness Therapy (FACIT), yang telah dilakukan uji validitas oleh (Sihombing, J. P., Hakim, L., Andayani, T.M, Irijanto, 2016), berupa I3 pernyataan dengan masing-masing jawaban memiliki rentang 0 sampai 4 . Pada kelompok kontrol, diukur gejala fatigue pada hari ke satu, kemudian diukur kembali gejala fatigue nya pada hari ke tujuh. Sedangkan pada kelompok intervensi, pada hari kesatu sebelum teknik relaksasi otot progresif pertama kali dilakukan, setiap responden diukur tingkat fatigue-nya untuk menetapkan besar skor awal. Selanjutnya kelompok intervensi melakukan latihan relaksasi otot progresif berturut-turut dimulai dari hari kesatu sampai ketujuh kemudian di ukur kembali gejala fatigue-nya.

Relaksasi Otot progresif adalah suatu metode relaksasi yang paling sederhana dan mudah dipelajari dengan menegangkan dan merilekskan otot-otot tubuh (Richmond, 2013). Relaksasi otot progresif merupakan salah satu intervensi keperawatan untuk meningkatkan relaksasi. Latihannya dapat membantu mengurangi ketegangan otot, stres, menurunkan tekanan darah, meningkatkan toleransi terhadap aktifitas sehari-hari, meningkatkan imunitas sehingga status fungsional dan kualitas hidup meningkat (Smeltzer, Suzanne C. dan Bare, 2002). Relaksasi otot progresif adalah gerakan mengencangkan dan melemaskan otot-otot pada satu bagian tubuh pada satu waktu untuk memberikan perasaan relaksasi secara fisik. Gerakan mengencangkan dan melemaskan otot secara progresif ini dilakukan secara berturut-turut (Lindquist, $R$, Snyder, M., Tracy, 2002). Pada kegiatan relaksasi ini perhatian pasien diarahkan untuk membedakan perasaan yang dialami saat kelompok otot dilemaskan dan dibandingkan ketika otot-otot dalam kondisi tegang.

Relaksasi merupakan salah satu bentuk mind-body therapy dalam terapi komplementer dan alternatif, yang merupakan bagian dari strategi kognitif-perilaku (Price, S.A., Wilson, 2006). Pelaksanaannya dapat dilakukan bersamaan dengan terapi medis. Relaksasi otot progresif telah menunjukkan manfaat dalam menurunkan gejala fatigue. Penelitian (Antoni, A, Dharmajaya, R dan Harahap, 20I5) didapatkan hasil terdapat perbedaan gejala fatigue yang signifikan sebelum dan sesudah dilakukan relaksasi otot progresif 
pada kelompok intervensi $(\mathrm{t}=43,57, \mathrm{p}=<0,00 \mathrm{I})$ pada kelompok kontrol $(t=1,73, p=0,093)$. Ditemukan perbedaan gejala fatigue yang signifikan pada kelompok intervensi $(t=30,453, \quad P=<0,001)$; sehingga berdasarkan hasil penelitian dapat disimpulkan bahwa relaksasi otot progresif dapat menurunkan gejala fatigue pada klien DM tipe 2.

\section{HASIL DAN PEMBAHASAN}

a. Karakteristik Responden

Tabel I

Distribusi Frekuensi Responden Menurut Karakteristik Responden

\begin{tabular}{|c|c|c|c|c|}
\hline \multirow{3}{*}{$\begin{array}{c}\text { Karakteristik } \\
\text { Responden }\end{array}$} & \multicolumn{4}{|c|}{$\mathbf{N}(\%)$} \\
\hline & \multicolumn{2}{|c|}{ Intervensi } & \multicolumn{2}{|c|}{ Kontrol } \\
\hline & $\mathbf{N}$ & $\%$ & $\mathbf{N}$ & $\%$ \\
\hline \multicolumn{5}{|l|}{ Usia } \\
\hline Lansia ( $\geq 55$ tahun) & 9 & 60 & 5 & 33.3 \\
\hline Dewasa (25-54 tahun) & 6 & 40 & 10 & 66.7 \\
\hline Total & 15 & 100 & 15 & 100 \\
\hline \multicolumn{5}{|l|}{ Jenis Kelamin } \\
\hline Perempuan & 12 & 80 & 12 & 80 \\
\hline Laki-Laki & 3 & 20 & 3 & 20 \\
\hline Total & 15 & 100 & 15 & 100 \\
\hline \multicolumn{5}{|l|}{ Pendidikan } \\
\hline Rendah & 10 & 66.7 & 13 & 86.7 \\
\hline Tinggi & 5 & 33.3 & 2 & 13.3 \\
\hline Total & 15 & 100 & 15 & 100 \\
\hline \multicolumn{5}{|l|}{ Lama DM } \\
\hline$<$ I tahun & 2 & 13.3 & I & 6.7 \\
\hline I - 5 tahun & 12 & 80 & 12 & 80 \\
\hline$>5$ tahun & I & 6.7 & 2 & 13.3 \\
\hline Total & 15 & 100 & 15 & 100 \\
\hline
\end{tabular}

Dari hasil analisis terhadap I5 responden didapatkan responden pada kelompok intervensi terbanyak berusia lansia yaitu sebesar 60\%, pada kelompok kontrol terbanyak berada pada usia dewasa yaitu $66.7 \%$. Distribusi jenis kelamin responden pada kelompok intervensi maupun kelompok kontrol didapatkan jumlah perempuan sama banyak yaitu $80 \%$. Distribusi responden berdasarkan pendidikan, antara kelompok intervensi dan kelompok kontrol hampir sama banyak, yaitu terbanyak berada pada pendidikan rendah, pada kelompok intervensi sebesar $66.7 \%$ dan pada kelompok kontrol sebesar $86.7 \%$. Distribusi lama menderita DM pada kelompok intervensi dan kelompok kontrol sama-sama jumlah yang terbanyak berada pada rentang lama menderita DM antara I sampai dengan 5 tahun, yaitu sebesar $80 \%$.

\section{b. Gejala Fatigue}

Data gejala fatigue responden dalam penelitian ini dilakukan pada 30 orang responden, yang terdiri dari 15 orang kelompok kontrol dan 15 orang kelompok intervensi.

Tabel 2

Distribusi Frekuensi Menurut Gejala Fatigue Pada Kelompok Kontrol dan Kelompok Intervensi Sebelum dan Sesudah Intervensi

\begin{tabular}{ccccc}
\hline Kelompok & $\begin{array}{c}\text { Gejala } \\
\text { Fatigue }\end{array}$ & Frek & $\%$ & N \\
\hline Kontrol (Pre) & Berat & 12 & 80 & 15 \\
& Ringan & 3 & 20 & \\
\multirow{3}{*}{ Kontrol (Post) } & Berat & 11 & 73.3 & 15 \\
& Ringan & 4 & 26.7 & \\
Intervensi (Pre) & Berat & 15 & 100 & 15 \\
& Ringan & 0 & & \\
Intervensi (Post) & Berat & 4 & 26.7 & 15 \\
& Ringan & 11 & 73.3 & \\
\hline
\end{tabular}

Hasil analisa pada tabel 2 menunjukkan data distribusi frekuensi gejala fatigue pada kelompok kontrol dan kelompok intervensi, sebelum dan sesudah intervensi. Pada kelompok kontrol terdapat nilai gejala fatigue pada kelompok kontrol sebelum dan sesudah nilainya tidak jauh berbeda yaitu responden lebih banyak mengalami gejala fatigue berat ( $80 \%$ pada kelompok sebelum) dan 73.3\% pada kelompok kontrol setelah intervensi. Sedangkan pada responden kelompok intervensi sebelum intervensi didapatkan gejala fatigue berat dari $100 \%$ yang kemudian setelah dilakukan intervensi ditemukan gejala fatigue berat sebesar $26.7 \%$.

c. Uji Normalitas dan Uji Hipotesis

Uji normalitas digunakan untuk menguji apakah data yang akan digunakan berdistribusi normal atau tidak. Hasilnya didapatkan hasil pengujian menggunakan pengujian non parametrik yaitu uji Wilcoxon.

d. Uji Wilcoxon Pada Kelompok Kontrol Sebelum dan Sesudah Perlakuan 
Hasil signifikansi p-value sebesar 0.469 (> 0.05) maka Ho diterima, sehingga kesimpulannya tidak terdapat perbedaan bermakna gejala fatigue pada kelompok kontrol yang hanya diberikan kombinasi terapi $\mathrm{OHO}$ dengan kondisi sesudah pengukuran gejala fatigue yang kedua pada hari ketujuh (dengan pemberian terapi OHO saja).

e. Uji Wilcoxon Pada Kelompok Intervensi Sebelum dan Sesudah Perlakuan

Hasil signifikansi p-value sebesar $0.002(<0.05)$ maka Ho ditolak, sehingga kesimpulannya terdapat perbedaan bermakna gejala fatigue pada kelompok sebelum diberikan kombinasi terapi $\mathrm{OHO}$ dan relaksasi otot progresif dengan kondisi sesudah dilakukan perlakuan, yaitu pemberian terapi $\mathrm{OHO}$ dan relaksasi otot progresif pada kelompok intervensi. Hal ini menunjukkan terdapat penurunan gejala fatigue pada kelompok intervensi sebelum dan setelah dilakukan terapi kombinasi $\mathrm{OHO}$ dan latihan relaksasi otot progresif (sebelumnya rata-rata responden kelompok intervensi mengalami gejala fatigue berat, setelah di lakukan intervensi, rata-rata nilai gejala fatigue berubah menjadi fatigue ringan).

Hasil penelitian didapatkan jumlah responden kelompok intervensi terbanyak berada pada usia lansia (60\%) sedangkan pada kelompok kontrol terbanyak berada pada usia dewasa (66.7\%). Proses menua yang berlangsung setelah usia 30 tahun mengakibatkan perubahan anatomis, fisiologis dan biokimia. WHO menyatakan bahwa setelah usia 30 tahun maka kadar glukosa darah akan naik I-2 $\mathrm{mg} / \mathrm{dl} /$ tahun pada saat puasa dan akan naik 5,6-13 mg/dl pada 2 jam setelah makan (Sudoyo, 2009). Meningkatnya gejala fatigue berkaitan dengan usia (Seo, Y.M., Hahm, J.R., Kim, T.K., Choi, 20I5). Semakin bertambahnya usia seseorang maka akan semakin rentan terjadinya kelelahan atau fatigue (Singh, 2013). Dari hasil penelitian yang dilakukan oleh (Seo, Y.M., Hahm, J.R., Kim, T.K., Choi, 20I5) kepada 180 klien DM tipe 2 yang dilakukan di Korea, di dapatkan hasil bahwa terdapat hubungan antara usia dengan gejala fatigue. Seiring bertambahnya umur, kelelahan akan sering dirasakan, hal tersebut di sebabkan oleh terjadinya penurunan kekuatan serta ketahanan otot, dan kemudian kelelahan akan semakin meningkat. ((Williams, L. S., \& Hopper, 2007).

Dari hasil penelitian ditemukan data jenis kelamin responden perempuan pada kelompok intervensi dan kelompok kontrol sama-sama menempati jumlah terbanyak, yaitu $80 \%$ Hal ini sebanding dengan, prevalensi DM pada tahun 2018 berdasarkan diagnosis dokter, jenis kelamin, dan daerah domisili. Berdasarkan kategori usia, penderita DM terbesar berada pada rentang usia 55-64 tahun dan 65-74 tahun. Selain itu, penderita DM di Indonesia lebih banyak berjenis kelamin perempuan $(1,8 \%)$ daripada laki-laki (I,2\%). Kemudian untuk daerah domisili lebih banyak penderita diabetes melitus yang berada di perkotaan (I,9\%) dibandingkan dengan di pedesaan (I,0\%) (RI, 20I8).

Angka total penderita diabetes diprediksi akan terus mengalami peningkatan dan diproyeksi akan mencapai 16,7 juta jiwa pada tahun 2045. WHO memprediksikan bahwa pada tahun 2025 akan terjadi peningkatan prevalensi diabetes, yaitu menjadi 300 juta jiwa, dan I50 juta jiwanya berasal dari wilayah Asia Pasifik (RI, 2018).

Hasil penelitian pada kelompok intervensi dan kelompok kontrol untuk kategori lama menderita DM didapatkan hasil yang sama banyak, yaitu berada pada rentang antara I sampai 5 tahun sebanyak $80 \%$. Lamanya durasi penyakit diabetes menunjukkan berapa lama pasien tersebut menderita diabetes melitus sejak ditegakkan diagnosis penyakit tersebut. Durasi lamanya diabetes melitus yang diderita ini 
dikaitkan dengan resiko terjadinya beberapa komplikasi yang timbul sesudahnya. Faktor utama pencetus komplikasi pada diabetes melitus selain lama menderita adalah tingkat keparahan diabetes. Akan tetapi lamanya durasi diabetes yang diderita diimbangi dengan pola hidup sehat akan menciptakan kualitas hidup yang baik, sehingga dapat mencegah atau menunda komplikasi jangka panjang (Zimmet, 2009).

Pada kelompok kontrol terdapat nilai gejala fatigue sebelum dan sesudah nilainya tidak jauh berbeda yaitu responden lebih banyak mengalami gejala fatigue berat ( $80 \%$ pada pengukuran hari pertama) dan $73.3 \%$ pada kelompok kontrol pada pengukuran kedua (7 hari setelah pengukuran pertama). Pada responden kelompok intervensi sebelum intervensi didapatkan gejala fatigue berat sebesar $100 \%$, setelah dilakukan intervensi ditemukan gejala fatigue berat turun menjadi 26.7\%. Hasil penelitian (HasanpourDehkordi \& Jalali, 2016) didapatkan hasil tidak ada perbedaan yang signifikan pada skor rata-rata fatigue severity sebelum intervensi antara kelompok intervensi dan kelompok kontrol, tetapi ada perbedaan yang signifikan secara statistik pada fatigue severity antara kelompok intervensi dan kelompok kontrol.

Dari hasil uji diperoleh bahwa tidak terdapat perbedaan bermakna gejala fatigue pada kelompok kontrol yang hanya diberikan terapi $\mathrm{OHO}$, pada pengukuran hari ke satu dengan hari ke tujuh. Dari hasi uji didapatkan hasil terdapat perbedaan bermakna gejala fatigue pada kelompok intervensi antara sebelum dan sesudah diberikan kombinasi terapi $\mathrm{OHO}$ (obat hipoglikemik oral) ditambah perlakuan relaksasi otot progresif. $\mathrm{Hal}$ ini selaras dengan penelitian (Antoni, A, Dharmajaya, R dan Harahap, 2015) yaitu terdapat perbedaan gejala fatigue yang signifikan sebelum dan sesudah pemberian relaksasi otot progresif pada kelompok intervensi $(t=43.57, p=<0.001)$, kelompok kontrol $(\mathrm{t}=1.73, \mathrm{p}=0.093)$ sehingga dapat disimpulkan bahwa relaksasi otot progresif dapat menurunkan gejala fatigue pada klien DM tipe 2.

Dari hasil uji Mann-Whitney diperoleh hasil ada perbedaan yang signifikan selisih mean gejala fatigue antara kelompok kontrol dengan kelompok intervensi setelah dilakukan perlakuan. Hasil penelitian (Hasanpour-Dehkordi \& Jalali, 2016) menunjukkan bahwa ada perbedaan yang signifikan secara statistik dalam skor kualitas hidup antara kelompok intervensi dan kelompok kontrol setelah intervensi sehingga relaksasi otot progresif meningkatkan kualitas hidup dan kesehatan pada pasien kelompok intervensi. Tapi, tidak ada perubahan yang dicatat dalam skor kualitas hidup pasien dalam kelompok kontrol. Hasil juga menunjukkan tidak ada perbedaan yang signifikan pada skor rata-rata fatigue severity sebelum intervensi antara kelompok intervensi dan kelompok kontrol, tetapi ada perbedaan yang signifikan secara statistik pada fatigue severity antara kelompok intervensi dan kelompok kontrol.

\section{KESIMPULAN}

Kesimpulan dari penelitian bahwa relaksasi otot progresif sebagai salah satu terapi non farmakologi dan termasuk kedalam terapi komplementer merupakan intervensi independen perawat untuk membantu menurunkan gejala fatigue yang sering muncul pada pasien DM tipe 2, karena dapat menimbulkan rasa nyaman dan relaksasi pada klien.

\section{UCAPAN TERIMA KASIH}

Penulis mengucapkan terima kasih kepada Direktur Poltekkes Kemenkes Palangka Raya, Kepala Pusat Penelitian dan Pengabmas beserta staf, responden penelitian, enumerator dan seluruh pihak yang telah membantu. 


\section{REFERENSI}

I. World Health Organization. (20I6). Global Report On Diabetes. https://apps.who.int/iris/bitstream/handle/ I0665/2 0487 I/978924I565257 eng.pdf;jsessionid=CA5 I 3 476DDBCCAD673ED3E476C839DDC?sequence $=1$

2. Kalra, S., \& Sahay, R. (2018). Diabetes Fatigue Syndrome. Diabetes Therapy. https://doi.org//0.1007/s |3300-018-0453-x

3. Seo, Y.M., Hahm, J.R., Kim, T.K., Choi, W. . (20I5). Factors Affecting Fatigue in Patients with Type II Diabetes Mellitus in Korea. Asean Nursing Research. https://doi.org/10.1016/j.anr.2014.09.004

4. Tarwaka. (20I3). Ergonomi Industri. Harapan Press.

5. Maurits, L. S. (20I0). Selintas Tentang Kelelahan Kerja. Amara Books.

6. Tarwaka., Solichul HA., B. dan L. S. (2004). Ergonomi Untuk Keselamatan, Kesehatan Kerja dan Produktivitas. Uniba Press.

7. Bridger, R. (2003). Introduction to Ergonomic 2nd Edition. Taylor \& Francis.

8. Koesyanto, H dan Pawenang, E. . (2005). Panduan Praktikum Laboratorium Kesehatan dan Keselamatan Kerja. UPT UNNES Press.

9. Sihombing, J. P., Hakim, L., Andayani, T.M, Irijanto, F. (20/6). Validation of Indonesian Version of FACIT Fatigue Scale Questionnaire in Chronic Kidney Disease (CKD) Patients with Routine Hemodialysis. Indonesian Journal of Clinical Pharmacy, 5(4), $231-237$. https://doi.org/10.15416/ijcp.2016.5.4.231

10. Richmond, R. L. (20I3). A guide to psychology and its practice: Progressive muscle relaxation. http://www.guidetopsychology.com/pmr.htm

II. Smeltzer, Suzanne C. dan Bare, B. G. (2002). Buku Ajar Keperawatan Medikal Bedah Brunner dan Suddarth (Ed.8, Vol. I,2). EGC.

12. Lindquist, R, Snyder, M., Tracy, M. . (2002). Complementary Alternative Therapies in Nursing, 4th Edition. Springer Publishing Company.

13. Price, S.A., Wilson, L. . (2006). Patofisiologi : Konsep Klinis Proses-. Proses Penyakit, Edisi 6, Volume I. EGC.

I4. Antoni, A, Dharmajaya, R dan Harahap, I. A. (20I5).
Pengaruh Progressive Muscle Relaxation Terhadap Gejala Fatigue pada Klien Diabetes Melitus Tipe 2. Jurnal Riset Keperawatan Indonesia Vol.3 No.2 Fak.Keperawatan USU.

15. Sudoyo, A. W. (2009). Buku Ajar Ilmu Penyakit Dalam, jilid II, edisi V. Interna Publishing.

16. Singh, R. (20/3). Understanding Fatigue in Persons with Type 2 Diabetes: A Mixed Methods Study. https://kuscholarworks.ku.edu/handle//808//4I86

17. Williams, L. S., \& Hopper, P. D. (2007). Understanding medical surgical nursing $3 r d$ ed. Davis Company.

18. RI, 'Badan Penelitian dan Pengembangan Kesehatan Kementerian. (2018). Riset Kesehatan Dasar (Riskesdas) (2018. http://www.depkes.go.id/resources/download/info terkini/materi_rakorpop_2018/Hasil Riskesdas 2018.pdf

19. Zimmet, P. (2009). Preventing diabetic complications: a primary care perspective. Diabetes research and clinical practice.

https://pubmed.ncbi.nlm.nih.gov//9278746/

20. Hasanpour-Dehkordi, A., \& Jalali, A. (2016). Effect of progressive muscle relaxation on the fatigue and quality of life among iranian aging persons. Acta Medica Iranica, 54(7), 430-436. https://pubmed.ncbi.nlm.nih.gov/27424013/

2I. Fritschi C, C, Quinn, L, Hacker, E.D, Penckofer, S.M, et al. (n.d.). Fatigue in women with type 2 diabetes. https://www.ncbi.nlm.nih.gov/pmc/articles/PMC40 06984/ pdf/nihms56/609.pdf 